\title{
VALIDATION OF ASSAY PROCEDURES OF AFOBAZOLEIN MICROCAPSULES
}

\section{POLKOVNIKOVA YULIA ALEKSANDROVNA*, SLIVKIN ALEKSEI IVANOVICH, HALAHAKOON AMILA JEEWANTHA}

Department of Pharmaceutical Chemistry and Pharmaceutical Technology, Faculty of Pharmacy, Voronezh State University, 394006, Voronezh, Street, Studentcheskaya,

Email: juli-polk@mail.ru

Received: 19 Dec 2017 Revised and Accepted: 20 Mar 2017

\begin{abstract}
Objective: The aim of this work was focused on a simple, rapid, accurate and sensitive method for quantitative analysis of afobazole in microcapsules (afb-m) using high-performance liquid chromatography (HPLC) with ultraviolet (UV) detection.
\end{abstract}

Methods: The analytical procedure was based on the fractionation characteristics of the afobazole in the chromatography column. The chromatography parameters «Zorbax extend-C18» column $(150 \times 2.1 \mathrm{~mm}$ i.d. $5 \mu \mathrm{m}$ particle size $)$, at $40{ }^{\circ} \mathrm{C}$. The isocratic mobile phase was $5.0 \mathrm{M}$ ammonium phosphate buffer ( $\mathrm{pH} 7.0)$ : acetonitrile (30:70; v/v) at a flow rate of at $1.0 \mathrm{ml}^{\mathrm{min}} \mathrm{m}^{-1}$. The determinations were performed using UV-Vis detector set at $220 \mathrm{~nm}$

Results: An assay procedure for afb-m has been validated from indices, such as specificity, correctness, precision, and linearity. The registered retention time of the afobazole stock solution and the sample solution was 1.5 min. The determined accuracy of the method was in the range of 99.67\%-100.67\%. The analytical curve was linear ( $\left.\mathrm{r}^{2}-0.9996\right)$ over a wide concentration range (50\%-150\%). The method showed sufficient precision, with a relative standard deviation (RSD) smaller than $2 \%$.

Conclusion: The HPLC method developed in this study showed specificity and selectivity with linearity in the working range and good precision and accuracy, making it very suitable for quantification of afb-m. The developed assay procedure of afb-m was meeting all the requirements of ICH validation criteria and can be applied for standardisation drug form afb-m.

Keywords: Afobazole, HPLC, Microcapsules, Validation

(C) 2017 The Authors. Published by Innovare Academic Sciences Pvt Ltd. This is an open access article under the CC BY license (http://creativecommons.org/licenses/by/4.0/) DOI: http://dx.doi.org/10.22159/ijpps.2017v9i5.16684

The present days, in the family of particular anxiolytics drugs, appeared-a selective anxiolytic afobazole $囚$. Afobazole has a complex of the anxiolytic effect manifested by reducing mental and somatic (vegetative) anxiety symptoms with a light psychoactive effect [1]. There are no muscle relaxant properties, a negative impact on memory and attention, also using afobazole was not forming an addiction and does not develop withdrawal symptoms. The tableted dosage formulation of afobazole was frequently prescribed by medical consultants, as a result of popularity and effectiveness and lack of the variety of afobazole dosage formulations requires nove dosage forms [2-4]

The physicochemical, biopharmaceutical and technological research was carried out by the department of pharmaceutical chemistry and technology in Voronezh state university was proposed the enhance dosage formulation: a microencapsulated formulation of afobazole, obtained by dispersing in the "liquid-liquid" system [5-9].

The validation of an analytical method must demonstrate that it fulfils all the requirements of the analytical applications, ensuring the reliability of the results. For this reason, the tests must show that its specificity, linearity, precision, sensitivity, accuracy are adequate for the analysis. The quantitative determination method of afobazole in microcapsules must be validated following the requirements criteria: specificity, linearity, accuracy, and precision according to the recommendations of the international council for harmonization of technical requirements for pharmaceuticals for human use (ICH) $[10,11]$. The main purpose of this work was conducting validation procedure of afb-m

In this experiment was used: liquid chromatograph Agilent 1100 (Agilent technologies, Japan), UV diode array detector (Agilent technologies, Japan), «Zorbax extend-C18» column (Agilent technologies, Japan), acetonitrile (uf210, Russia), ammonium phosphate (manufactured by Sigma in Germany, and Fluka in Switzerland). Afobazole (fabomotizole) standard samples were synthesized by the Italian firm Erregiere and chemical-technological laboratory research and technology department of the research institute of pharmacology in Russia, was meeting the requirements of the regulatory document "afobazole 42-13869-05.

The object of this research was the microencapsulated afobazole (afb-m). The afb-m used in the studies was obtained by the method of dispersion in the "liquid-liquid" system. The method was performed on the liquid chromatograph agilent 1100 and determination conducted by the UV-vis diode array detector at the wavelength $220 \mathrm{~nm}$. The following conditions were applied: reversed phase $2,1 \times 150 \mathrm{~mm}$ size «Zorbax extend-C18» column filled with the $5 \mu \mathrm{m}$ size particles, $1.0 \mathrm{ml}$. min-1 mobile phase (MP) flow rate, column temperature $40{ }^{\circ} \mathrm{C}$, multi-wavelength detection mode and the column thermos tasting temperature mode. For the preparation of MP was used acetonitrile and the buffer system $(\mathrm{pH}$ 7.0) which was consisting of $5.0 \mathrm{M}$ ammonium phosphate solution with a volume ratio of $30: 70(\mathrm{v} / \mathrm{v})$. For the microencapsulation process used a standard sample of afobazole with $98.5-101 \%$ purity without further purification.

The standard solution of afobazole was prepared using afobazole standard samples. Accurately weighed $0.030 \mathrm{~g}$ was transferring into $100 \mathrm{ml}$ volumetric flask and was dissolved five minutes in the ultrasonic bath by adding $80 \mathrm{ml}$ of MP. After the full dissolution of afobazole, the solution volume was adjusted with the same solvent to $100 \mathrm{ml}$. The solution was accurately stirred for the solution homogeneity and filtered through a membrane filter with a pore size of $0.2-0.45 \mathrm{~mm}$.

Accurately weighed $0.100 \mathrm{~g}$ porphyrized microcapsules powder was used to prepare the test solution and followed the same procedure, which was used to preparing the standard solution with discarding the first portion of the filtrate. The only fresh solutions were used in the experiment work.

The chromatogram of the afobazole standard solution was obtained by applying above described chromatographic conditions. The 
specificity and selectivity describe the capacity of the analytical method to measure the drug in the presence of impurities, excipients, degradation products or matrix components. These parameters were determined by comparing the chromatograms of the afobazole standard solution and test solution. The chromatogram of the afobazole standard solution presented a peak in the time retention of 1.5 min (fig. 1). The chromatogram of afb-m solution (test solution) (fig. 2) showed a peak and retention time similar to afobazole standard solution. The components of the microcapsules do not interfere with the analysis; therefore, no peak is observed in the region of the main peak of afobazole (fig. 2). The chromatogram peaks are well resolved, indicating the high specificity of the method.

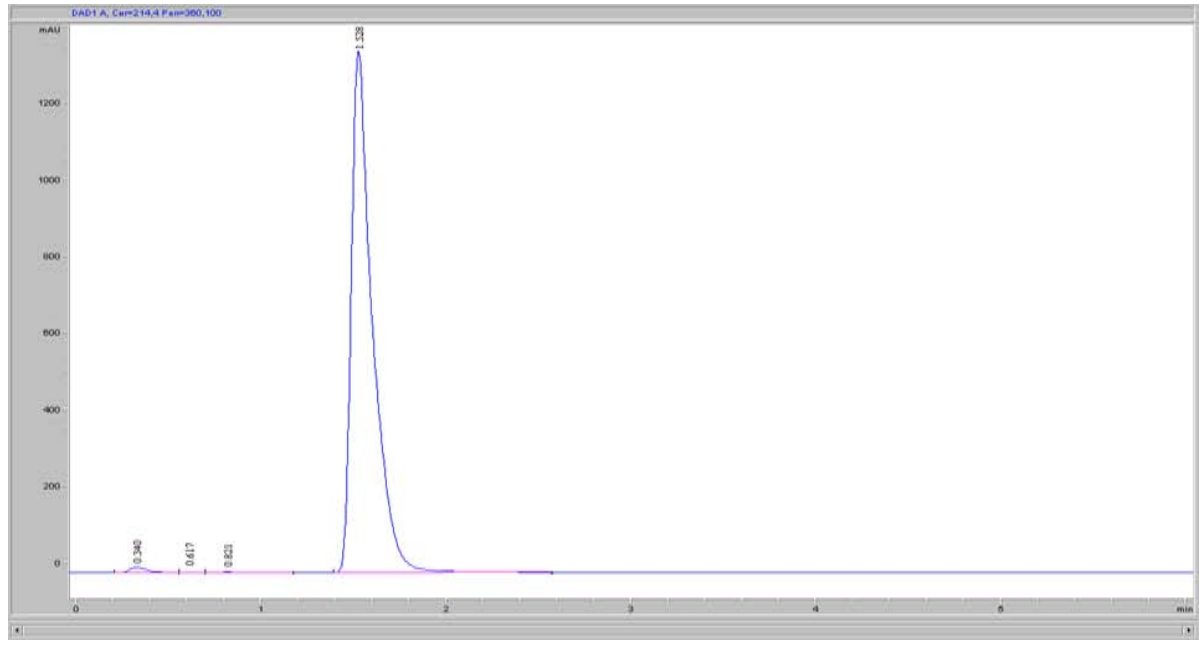

Fig. 1: HPLC chromatogram of the afobazole standard sample solution

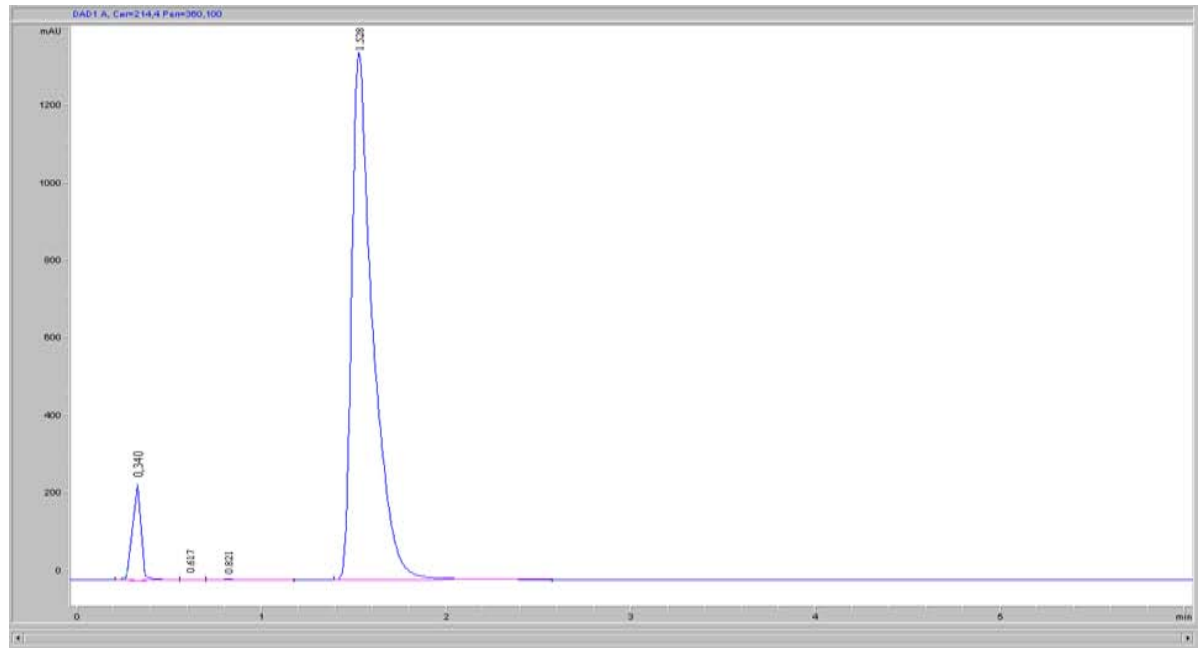

Fig. 2: HPLC chromatogram of the afobazole extraction from the microcapsules

Accuracy is one of the most important parameters of an analytical methodology, and it can be expressed as the percent recovery of known amounts of drug added to a sample.

For studies of the determination accuracy of the analytical method was carried out using afobazole model mixtures solution with a concentration range $50 \%-150 \%$ of standard solution concentration. The openability value (R) of the model mixtures and afobazole standard solution were measured. The percentage concentration of afobazole (X \%) in the samples and model mixtures was calculated using the formula (1).

$$
\mathrm{X}=\frac{\mathrm{S}_{\mathrm{i}} * \mathrm{~m}_{0} * 100 * 100}{\mathrm{~S}_{0 \mathrm{i}} * \mathrm{~m} * 100}=\frac{\mathrm{S}_{\mathrm{i}} * \mathrm{~m}_{0} * 100}{\mathrm{~S}_{0 \mathrm{i}} * \mathrm{~m}},(1)
$$

Where,

$\mathrm{m}_{0-\mathrm{a}}$ weighed portion of the afobazole standard sample used to prepare the reference solution, (g); m-a weighed portion of the microcapsule powder used to prepare the test solution sample, (g);

$S_{i}$-the mean value of the peak areas, computed from the chromatogram of the afobazole test solution;

$\mathrm{S}_{o i}$-the mean value of the peak areas, calculated from the chromatogram of the afobazole reference solution.

The precision was calculated from an average of six determinations of a homogeneous sample. The precision assays were expressed as relative standard deviation (RSD) 0.47 , indicating that the method presents a good precision. The detailed precision data are shown in table 1.

The linearity of the method was established by analysing of afobazole model mixtures series consists in the range $50-150 \%$ of standard solution concentration. The analytical curve was constructed by plotting the area under the curve (AUC) of the main peak versus drug concentration, with a calculating correlation coefficient r (fig. 3). 


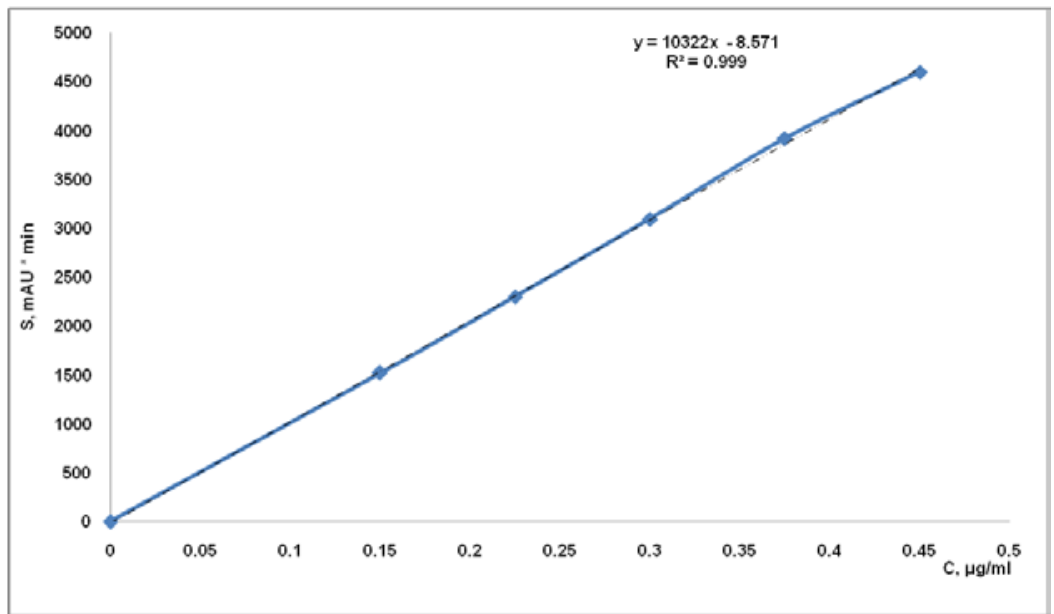

Fig. 3: The variation of the area under the chromatographic peak against to the afobazole concentration in the solution

The characteristics of the validation method were presented in table 1.

Table 1: Validation characteristics of the methodology for determining the afobazole in the microcapsules

\begin{tabular}{|c|c|c|c|c|c|}
\hline The characteristics & \multirow{3}{*}{$\begin{array}{l}\text { Admissibility criteria } \\
\begin{array}{l}\mathrm{R}+\Delta \mathrm{R} \text { (openability) must belong to } \\
\text { the interval } 98-102 \%\end{array}\end{array}$} & \multicolumn{3}{|l|}{ Results } & \multirow{2}{*}{$\begin{array}{l}\text { Compliance with the } \\
\text { criterion of admissibility } \\
\text { Complied } \\
\text { Complied }\end{array}$} \\
\hline Specificity & & \multicolumn{3}{|c|}{$\begin{array}{l}\text { Overlapping the retention time peaks in the } \\
\text { chromatograms of the afobazole sample } \\
\text { solution and standard solution. }\end{array}$} & \\
\hline Accuracy & & $\begin{array}{l}\% \\
50 \\
75 \\
100 \\
125 \\
150\end{array}$ & $\begin{array}{l}\mathrm{R}-\Delta \mathrm{R} \\
99.67 \\
98.30 \\
99.33 \\
98.33 \\
99.67\end{array}$ & $\begin{array}{l}\mathrm{R}+\Delta \mathrm{R} \\
101.67 \\
99.30 \\
100.33 \\
99.33 \\
100.67\end{array}$ & Complied \\
\hline $\begin{array}{l}\text { Precision- } \\
\text { repeatability }\end{array}$ & $\mathrm{RSD} \leq 2 \%(\mathrm{n}=6)$ & $\begin{array}{l}\text { Sample number } \\
1 \\
2 \\
3 \\
4 \\
5 \\
6 \\
\operatorname{RSD}, \%\end{array}$ & $\begin{array}{l}\mathrm{R}, \% \\
100.43 \\
98.77 \\
99.56 \\
101.34 \\
101.56 \\
99.15 \\
0.47\end{array}$ & & Complied \\
\hline Linearity & $\begin{array}{l}\text { 1. A linear dependency of peak area } \\
\text { against to the afobazole concentration } \\
\text { in the sample; } \\
2 \text {. The correlation coefficient } \mathrm{R}^{2} \geq \\
0,99\end{array}$ & $\begin{array}{l}\text { 1. Observing li } \\
\text { area against to } t \\
\text { (fig. 2); } \\
\text { 2. The correlat }\end{array}$ & $\begin{array}{l}\text { ar depe } \\
\text { concen } \\
\text { coeffic }\end{array}$ & $\begin{array}{l}\text { dence of the peak } \\
\text { ation afobazole } \\
\text { ent } \mathrm{R}^{2}=0,9996\end{array}$ & Complied \\
\hline
\end{tabular}

As the shown in fig. 3, the analytical curve for the afobazole standard sample was constructed by plotting the area under the curve (AUC) of the main peak versus drug concentration. It was found to be linear over a wide concentration range (50\%-150\%) with a correlation coefficient of 0.9996 . The straight line (trend line) equation obtained from the experimental results was found to be: $y=10322 x-8,5714$. The linearity parameters were founded in the experiment corresponds to the all the requirements criteria, the correlation coefficient was more than 0.99, which corresponds to the requirements of the state standard Russia ISO 5725 and ICH Q2 (R1).

The results were given in table 1 . was demonstrating, that the analytical method has sufficient accuracy over the selected concentration range (from $50 \%$ to $150 \%$ ). The relative standard deviation (RSD, \%) did not exceed 2\%. Thus, the afobazole determination method in the microcapsules was valid to concerning "correctness" and besides that, afobazole analysis technique has sufficient accuracy and precision and correctness. There were no any registered significant systematic errors in this method.

\section{CONCLUSION}

The results show that the HPLC method presented here can be considered suitable for the analytical determination of afobazole in microcapsules. The described method was meet al. 1 the validation requirements criteria and can make the conclusion that the validation procedure was accomplished. As a result of the high selectivity and acceptable level of sensitivity of the developed quantification method for afb-m can be recommended to apply for quality control purposes of afobazole in dosage formulations.

\section{ACKNOWLEDGEMENT}

The research was carried out with under the support of the grant Council for Grants of the President of the Russian Federation MK3317.2015.7.

\section{CONFLICTS OF INTERESTS}

Declared none 


\section{REFERENCES}

1. Seredenin SB, Voronin MV. Neuroreceptor mechanisms of action of afobazole. Russian J Exp Clin Pharmacol 2009;72:3-11.

2. Herrero EP, Del Valle, Martin EM, Galan MA. Development of a new technology for the production of microcapsules based in atomization processes. Chem Eng J 2006;117:137-42.

3. Sardushkin MV, Hodkova YuV, Kienskaja KI, Avramenko GV. To study the efficiency of microencapsulation and release kinetics of rifampicin from the microcapsules with polylacticacid shell. Chem Eng J 2010;4:233-8.

4. Senuma Y, Lowe C, Zweifel Y, Hilborn JG, Marison I. Alginate hydrogel microspheres and microcapsules prepared by spinning disk atomization. Biotechnol Bioeng 2000;67:616-22.

5. Shwinger C, Klemenz A, Busse K, Kressler J. Encapsulation of living cells with polymeric systems. Macromol Symp 2004;210:493-9.

6. Suchitra Panigrahi, Rajashree Hirlekar. A new stabilityindicating RP-HPLC method for determination of curcumin: an application to nanoparticulate formulation. Int J Pharm Pharm Sci 2016;12:102-7.
7. Sunitha S, Amareshwar P, Santhosh M. A study on the effect of different cellulose polymers on release rate from Tramadol loaded microspheres prepared by an emulsion solvent evaporation method. Asian J Pharm Clin Res 2010;3:35-9.

8. Hamsika M, Gowda DV, Jigyasa Vindru, Afrasim Moin Nanotechnology for ophthalmic preparations. Int J Curr Pharm Res 2016;8:5-11.

9. Marilene Estanqueiro, Maria Helena Amaral, Jaime Conceição, José Manuel, Sousa Lobo. Evolution of liposomal carriers intended to anticancer drug delivery: an overview. Int J Curr Pharm Res 2015;7:26-33.

10. ICH harmonized tripartite guidelines Q2A Text on validation of analytical procedures, ICH, Geneva; 1995.

11. ICH harmonized tripartite guidelines Q2B validation of analytical procedures: methodology ICH, Geneva; 1997.

\section{How to cite this article}

- Polkovnikova Yulia Aleksandrovna, Slivkin Aleksei Ivanovich, Halahakoon Amila Jeewantha. Validation of assay procedures of afobazolein microcapsules. Int J Pharm Pharm Sci 2017; $9(5): 278-281$. 